\title{
Yield and Water Use Efficiency of Green Maize Planted in Conditions Brazilian Semiarid
}

\author{
Edvaldo Eloy Dantas Junior ${ }^{1}$, Lúcia Helena Garófalo Chaves ${ }^{2}$ \\ ${ }^{1}$ Department of Technology Development, Federal University of Campina Grande (DTEC/UFCG), \\ Campina Grande, Brazil \\ ${ }^{2}$ Department of Agricultural Engineering, Federal University of Campina Grande (DEAG/UFCG), \\ Campina Grande, Brazil \\ Email: edvaldoeloyj@@gmail.com, Ihgarofalo@hotmail.com
}

Received 19 March 2014; revised 19 April 2014; accepted 7 May 2014

Copyright (C) 2014 by authors and Scientific Research Publishing Inc.

This work is licensed under the Creative Commons Attribution International License (CC BY).

http://creativecommons.org/licenses/by/4.0/

(c) (i) Open Access

\section{Abstract}

This study investigated the water use efficiency and yield for the production of green ears of corn subjected to irrigation with drip system and with potassium fertilizer levels in Sumé, Paraiba State, Brazil. The experimental design was a randomized design with four replications in a split plot design with six water slides (0.25 ETcp, 0.50 ETcp, 0.75 ETcp, 1.00 ETcp, 1.25 ETcp and 1.50 ETcp) and six doses of potassium $\left(0,20,40,60,80\right.$ and $\left.100 \mathrm{~kg} \cdot \mathrm{ha}^{-1}\right)$. The maize hybrid AG 1051 was mechanically sown on 13/01/2012 and the spikes in the green stage (doughy grains) were harvested 67 days after planting. Water consumption for producing one ton of maize cobs in the slides 132, $264,396,528,660$, and $792 \mathrm{~mm}$ of water within all treatments of potassium fertilization increased, indicating that the WUE decreases with the increasing amount of water applied via irrigation. Therefore, it was observed that the water use efficiency average was $61.76 \mathrm{~mm} \cdot \mathrm{t}^{-1}\left(2.02 \mathrm{~kg} \cdot \mathrm{m}^{3}\right)$, i.e. for each $\mathrm{m}^{3}$ of water used $2.02 \mathrm{~kg}$ of ears of corn were produced with default. The application of $680.64 \mathrm{~mm}$ of water and $72.14 \mathrm{~kg} \cdot \mathrm{ha}^{-1}$ potassium maximized the yield of ears, resulting in the maximum yield of ears of $10.82 \mathrm{t} \cdot \mathrm{ha}^{-1}$.

\section{Keywords}

Potassium, Drip Irrigation, Productivity, Zea mays L.

\section{Introduction}

Maize (Zea mays L.) is a major cereal produced in the world and the most cultivated in Brazil, practically the 
entire territory, however, there is a enormous contrast in productivity among different regions of the country, due to the different climates and cultivation conditions to which culture is submitted. The cultivation of this cereal is well adapted to tropical and subtropical regions, however, [1] emphasized that the yield of corn in the northeastern region is low, because of the predominance of production systems that use little or no technology and there are usually, in this region, failure and irregular rainfall. Corroborating this idea [2] pointed out that the failure or irregular distribution of rainfall is a major factor limiting agricultural production in Brazil, yet occurred in recent years, a significant increase in the cultivation of maize under irrigation.

The dissemination of techniques for systematic production processes, with intensification of plantations profitable cultivars is of fundamental importance, by virtue to optimize the use, in particular water and soil. Scientists from all over the world look to the studies correlated to water use efficiency (WUE) which is an important measure that shows the relationship between the unit dry matter produced and unit of water used. According to [3] water use efficiency (WUE) is one of the ways to analyze the response of crops to different conditions of water availability as it relates to the production of dry biomass or commercial production with the amount of water applied evapotranspired or by culture. For El-Hendawy [4] the water use efficiency through modern irrigation systems is increasingly important in arid and semi-arid regions with limited water resources.

The methods of using water efficiently, seeking increased crop yield with quantitative under water, and what happens in well planned irrigation projects, are encouraged by many researchers in the world [5], considering that nowadays water is a limiting factor of various human activities.

It signaled that the use of irrigation techniques coupled with management of soil fertilization, provides higher economic returns in corn, although crops under irrigation should be planned for the greater financial return of production and less impact on the environment, since there is great environmental damage for excessive use of fertilizers [2] and excess water in irrigation.

Faced with the shortage of studies focused on the Brazilian semiarid region regarding irrigation management in areas with limited water resources, this research aimed to evaluate the water use efficiency (WUE) in the production of green corn spikes under conditions of Cariri Paraiba (subclima semiarid).

\section{Materials and Methods}

A field experiment was carried out in Sumé, Paraíba State, Brazil (3652'48"W, 0740'17"S; 532 m asl) on a Litholic Neosol soil with $641.5 \mathrm{~g} \cdot \mathrm{kg}^{-1}$ clay, $271.0 \mathrm{~g} \cdot \mathrm{kg}^{-1}$ silt and $87.5 \mathrm{~g} \cdot \mathrm{kg}^{-1}$ sand. The climate of the region is dry characterized by insufficient rainfall (monthly average in January, February and March 2012: 40.4 mm, 85.5 $\mathrm{mm}$ and $144.8 \mathrm{~mm}$, respectively; however in this year there was no precipitation event) and high temperatures; the average temperature is around $24^{\circ} \mathrm{C}$ [6].

Before sowing maize, the chemical properties of the surface layer $(0-0.20 \mathrm{~m})$ were determined according to [7], i.e. organic matter (OM), $13.4 \mathrm{~g} \cdot \mathrm{dm}^{-3}$; $\mathrm{pH}\left(\mathrm{H}_{2} \mathrm{O}\right)$ 7.63; P, $54 \mathrm{mg} \cdot \mathrm{dm}^{-3}$; K, Ca, Mg, and Na, 0.25; $10.6 ; 7.56$ and $0.07 \mathrm{cmol}_{\mathrm{c}} \cdot \mathrm{dm}^{-3}$, respectively.

The experiment was carried out in a randomized block design in a split-plot design with six water slides and six amounts of potassium in four replications, totaling 144 experimental units arranged in an area of $2086.56 \mathrm{~m}^{2}$ (Table 1).

In plots of $8.4 \times 10.4 \mathrm{~m}$ were placed slides of irrigation water determined based on crop potential evapotranspiration (ETcp) with levels: 0.25 ETcp, 0.50 ETcp, 0.75 ETcp, 1.00 ETcp, 1.25 ETcp and 1.50 ETcp. In 24 split plots whose dimensions were $3.0 \times 4.2 \mathrm{~m}$ (each split plots) were fertilized with different amounts of potassium (0, 20, 40, 60, 80 and $100 \mathrm{~kg} \cdot \mathrm{K} \cdot \mathrm{ha}^{-1}$, corresponding to $\mathrm{K}_{0}, \mathrm{~K}_{1}, \mathrm{~K}_{2}, \mathrm{~K}_{3}, \mathrm{~K}_{4}$ and $\mathrm{K}_{5}$, respectively).

The maize hybrid AG 1051 was mechanically sown on 13/01/ 2012 by planting in double rows of square arrangement (three double rows in each split plots). In each planting hole were placed 3 seeds and after germination were kept 2 plants per hole to production. The distance between plants was $0.4 \times 0.4 \mathrm{~m}$ and between irrigation lines was $1.4 \mathrm{~m}$ with a population of 71,000 plants $\cdot \mathrm{ha}^{-1}$. Manual harvesting of spikes in the green stage (doughy grains) occurred 67 days after planting.

According to the results of the soil chemical properties and fertilization recommendation for irrigated maize, in the foundation were placed $66.67 \mathrm{~kg} \cdot \mathrm{ha}^{-1}$ of urea and $105.26 \mathrm{~kg} \cdot \mathrm{ha}^{-1}$ of super-simple phosphate and more $133.33 \mathrm{~kg} \cdot \mathrm{ha}^{-1}$ of urea of covering [8]. The various doses of potassium followed the criterion of lower $(0,20$, $\mathrm{kg} \cdot \mathrm{ha}^{-1}$ ) and higher $\left(60,80\right.$ and $\left.100 \mathrm{~kg} \cdot \mathrm{ha}^{-1}\right)$ amounts of fertilizer recommendation $\left(40 \mathrm{~kg} \cdot \mathrm{ha}^{-1}\right)$ considering that $^{-1}$ this recommendation is designed for areas with very different soil and climatic characteristics of the area of this 
Table 1. Different treatments based on the water slides $(\mathrm{mm})$ and potassium doses $\left(\mathrm{kg} \cdot \mathrm{ha}^{-1}\right)$.

\begin{tabular}{|c|c|c|c|c|c|c|}
\hline \multirow{2}{*}{$\begin{array}{c}\text { Potencial } \\
\text { evapotranspiration } \\
\text { (ETcp) }\end{array}$} & \multicolumn{6}{|c|}{ Potassium $(\mathrm{K}), \mathrm{kg} \cdot \mathrm{ha}^{-1}$} \\
\hline & $\mathrm{K}_{0}-0$ & $\mathrm{~K}_{1}-20$ & $\mathrm{~K}_{2}-40$ & $\mathrm{~K}_{3}-60$ & $\mathrm{~K}_{4}-80$ & $\mathrm{~K}_{5}-100$ \\
\hline $\mathrm{W}_{1}-0.25$ & $\mathrm{~W} 1-\mathrm{K}_{0}$ & $\mathrm{~W} 1-\mathrm{K}_{1}$ & $\mathrm{~W} 1-\mathrm{K}_{2}$ & $\mathrm{~W} 1-\mathrm{K}_{3}$ & $\mathrm{~W} 1-\mathrm{K}_{4}$ & $\mathrm{~W} 1-\mathrm{K}_{5}$ \\
\hline $\mathrm{W}_{2}-0.50$ & $\mathrm{~W} 2-\mathrm{K}_{0}$ & $\mathrm{~W} 2-\mathrm{K}_{1}$ & $\mathrm{~W} 2-\mathrm{K}_{2}$ & $\mathrm{~W} 2-\mathrm{K}_{3}$ & $\mathrm{~W} 2-\mathrm{K}_{4}$ & $\mathrm{~W} 2-\mathrm{K}_{5}$ \\
\hline $\mathrm{W}_{3}-0.75$ & W3- $\mathrm{K}_{0}$ & W3-K ${ }_{1}$ & W3- $\mathrm{K}_{2}$ & $\mathrm{~W} 3-\mathrm{K}_{3}$ & W3- $\mathrm{K}_{4}$ & W3-K \\
\hline $\mathrm{W}_{4}-1.00$ & $\mathrm{~W} 4-\mathrm{K}_{0}$ & W4-K ${ }_{1}$ & $\mathrm{~W} 4-\mathrm{K}_{2}$ & $\mathrm{~W} 4-\mathrm{K}_{3}$ & $\mathrm{~W} 4-\mathrm{K}_{4}$ & W4-K 5 \\
\hline $\mathrm{W}_{5}-1.25$ & W5- $\mathrm{K}_{0}$ & W5- $\mathrm{K}_{1}$ & W5- $\mathrm{K}_{2}$ & $\mathrm{~W} 5-\mathrm{K}_{3}$ & $\mathrm{~W}-\mathrm{K}_{4}$ & W5- $\mathrm{K}_{5}$ \\
\hline $\mathrm{W}_{6}-1.50$ & W6- $\mathrm{K}_{0}$ & W6-K ${ }_{1}$ & W6-K ${ }_{2}$ & W6- $\mathrm{K}_{3}$ & W6-K $\mathrm{K}_{4}$ & W6-K \\
\hline
\end{tabular}

research. The potassium fertilization was carried out in the foundation, where the product was used potassium sulfate.

The irrigation system used was located with drippers. For estimation of local evaporation (EV) used the tank USWB class A, surrounded by exposed soil (circle with radius of $1.0 \mathrm{~m}$ from the tank). Based on relative humidity of air, lower than $40 \%$, and the average wind speed, $2.55 \mathrm{~m} \cdot \mathrm{s}^{-1}$, considered moderate, was adopted a coefficient of $0.65 \mathrm{Kt}$ tank which, multiplying with evaporation tank (EV) resulting in potential evapotranspiration value, mm·day ${ }^{-1}\left(\mathrm{ET}_{0}\right)$ [9]. To determine the potential evapotranspiration culture (ETcp), we used a lysimeter percolation of $4.50 \mathrm{~m}^{2}$ and depth of $1.50 \mathrm{~m}$. Dividing the value of potential evapotranspiration culture (ETcp) by reference potential evapotranspiration value $\left(\mathrm{ET}_{0}\right)$ obtains the value of the crop coefficient (Kc). This factor is important in the calculation of replacement water slides corresponding to $25 \%, 50 \%, 75 \%, 100 \%, 125 \%$ and $150 \%$ of ETcp.

The spikes were harvested and weighed 62 days after germination. After weighing in the useful area of the experimental plot (central double row of each split plots, measuring $3 \mathrm{~m}$ long and $0.4 \mathrm{~m}$ wide with area of 1.2 $\mathrm{m}^{2}$ ), it was made extrapolation to an area of one (1) hectare (ha), thereby obtaining the quantity, in tonnes per hectare $\left(\mathrm{t} \cdot \mathrm{ha}^{-1}\right)$.

The water use efficiency (WUE) $\left(\mathrm{kg} \cdot \mathrm{m}^{-3}\right)$ in the production of commercial spikes was calculated by dividing the yield of commercial spikes $\left(\mathrm{t} \cdot \mathrm{ha}^{-1}\right.$ ) by the volume of water used or the water depth (in mm) for produce spikes.

\section{Results and Discussion}

The average productivity of spikes, wherein the sources of variation were the amounts of water and potassium are shown in Table 2.

The depth of water, the potassium and the interaction between the two factors influenced significantly the yield of ears. The factors, individually, affecting the productivity of spikes at $1 \%$ probability, and the interaction between water and potassium influenced this productivity at level of 5\% statistical probability (Table 3).

The overall average of spikes that had diameters and lengths greater than 3 and $15 \mathrm{~cm}$, respectively, was 7.7 $\mathrm{t} \cdot \mathrm{ha}^{-1}$. Overall $88 \%$ of the yield of ears satisfied the quality standards required by the brasilian market (i.e. spikes that have length and diameter greater than $15 \mathrm{~cm}$ and $3 \mathrm{~cm}$, respectively, [10]).

The $\mathrm{W}_{5} \mathrm{~K}_{4}$ combination resulted in the highest yield of ears (13.58 $\left.\mathrm{t} \cdot \mathrm{ha}^{-1}\right)$ which exceeded the combination $\mathrm{W}_{1} \mathrm{~K}_{0}\left(2.08 \mathrm{t} \cdot \mathrm{ha}^{-1}\right)$ at 6.53 times. This can be explained by the fact that the experiment be conducted in the field with possible losses in the conduction of water from the station control until the treatments or even human failings in the management of irrigation which is acceptable.

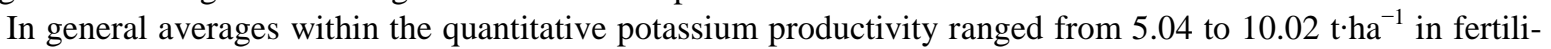
zation with potassium of 0 and $80 \mathrm{~kg} \cdot \mathrm{ha}^{-1}$, respectively. When the average yield of ears is analyzed within the depth of water, productivity ranged from 4.72 to $10.26 \mathrm{t}^{\cdot \mathrm{ha}^{-1}}$ at water depths of 132 and $660 \mathrm{~mm}$, respectively. This is because excess water in larger and potassium doses impairing green corn production.

Studies by [11] obtained a yield of ears of $4.35 \mathrm{t} \cdot \mathrm{ha}^{-1}$ under conditions of adequate irrigation and fertilizing. Moraes [12] obtained a yield of ears of $6.36 \mathrm{t} \cdot \mathrm{ha}^{-1}$ for cultivar AG 1051. Comparing data from this survey with those of these authors, there is superiority in the means obtained in this experiment, which points to a gain in 
Table 2. Ears of green corn production (t $\left.\cdot \mathrm{ha}^{-1}\right)$ as a function of the doses of potassium and water slides.

\begin{tabular}{|c|c|c|c|c|c|c|c|c|c|}
\hline \multicolumn{3}{|c|}{ Water slides } & \multicolumn{6}{|c|}{ Potassium (K), $\mathrm{kg} \cdot \mathrm{ha}^{-1}$} & \multirow{2}{*}{ Average } \\
\hline & ETcp (mm) & $\mathrm{m}^{3} \cdot \mathrm{ha}^{-1}$ & $\mathrm{~K}_{0}-0$ & $\mathrm{~K}_{1}-20$ & $\mathrm{~K}_{2}-40$ & $\mathrm{~K}_{3}-60$ & $\mathrm{~K}_{4}-80$ & $\mathrm{~K}_{5}-100$ & \\
\hline $\mathrm{W}_{1}$ & 132 & 1320 & 2.08 & 3.00 & 4.42 & 7.07 & 6.43 & 5.31 & 4.72 \\
\hline $\mathrm{W}_{2}$ & 264 & 2640 & 3.44 & 4.50 & 6.16 & 6.94 & 8.58 & 5.63 & 5.87 \\
\hline $\mathrm{W}_{3}$ & 396 & 3960 & 4.82 & 5.91 & 8.30 & 9.38 & 9.50 & 8.09 & 7.67 \\
\hline $\mathrm{W}_{4}$ & 528 & 5280 & 5.88 & 9.32 & 9.84 & 10.50 & 10.27 & 8.16 & 8.99 \\
\hline $\mathrm{W}_{5}$ & 660 & 6600 & 8.12 & 6.78 & 10.12 & 12.34 & 13.58 & 10.64 & 10.26 \\
\hline \multirow[t]{2}{*}{$\mathrm{W}_{6}$} & 792 & 7920 & 5.92 & 6.25 & 8.86 & 9.90 & 11.78 & 8.84 & 8.59 \\
\hline & \multicolumn{2}{|l|}{ Average } & 5.04 & 5.96 & 7.95 & 9.35 & 10.02 & 7.78 & \\
\hline
\end{tabular}

Table 3. Analysis of variance of the yield of ears.

\begin{tabular}{lccc}
\hline \multicolumn{1}{c}{ FV } & DF & SS & MS \\
Water slides (W) & 5 & 510.536 & 102.107 \\
Error-W & 18 & 50.663 & 2.814 \\
Plots & 23 & 516.199 & 87.717 \\
Potassium (K) & 5 & 438.586 & 2.478 \\
Int. W x K & 25 & 61.967 & 0.929 \\
Erro-K & 90 & 83.675 & $2.67^{*}$ \\
Total & 143 & 1145.428 & \\
CV of plots (W) $=21.83 \%$ & & & \\
CVof split plots $(\mathrm{K})=12.55 \%$ & & & \\
\hline
\end{tabular}

ns, * and **; Non significant and significant at the 5 and $1 \%$ levels of probability, respectively.

weight of corn, due to the treatments in question.

The water use efficiency in the international literature, is usually analyzed in ton of product per mega liter of water used $\left(\mathrm{ML} \cdot \mathrm{t}^{-1}\right)$ and kilograms of product per cubic meter of water used $\left(\mathrm{kg} \cdot \mathrm{m}^{-3}\right)$. However, to facilitate the economic analysis of irrigation, WUE data can also be interpreted based on water consumption, expressed in millimeters of water consumed per ton of corn produced $\left(\mathrm{mm} \cdot \mathrm{t}^{-1}\right)$.

The amount of water consumed per ton of ears of green corn produced increases whenever the water slides are differentiated (Table 4). The consumption of water to produce one ton of maize spikes in the slides 132, 264, 396, 528, 660, and $792 \mathrm{~mm}$ of water within all treatments of $\mathrm{K}$ fertilization was $34.4 \mathrm{~mm} \cdot \mathrm{t}^{-1}\left(3.6 \mathrm{~kg} \cdot \mathrm{m}^{-3}\right), 49.9$ $\mathrm{mm} \cdot \mathrm{t}^{-1}\left(2.2 \mathrm{~kg} \cdot \mathrm{m}^{-3}\right), 56.3 \mathrm{~mm} \cdot \mathrm{t}^{-1}\left(1.9 \mathrm{~kg} \cdot \mathrm{m}^{-3}\right), 61.6 \mathrm{~mm} \cdot \mathrm{t}^{-1}\left(1.7 \mathrm{~kg} \cdot \mathrm{m}^{-3}\right), 68.6 \mathrm{~mm} \cdot \mathrm{t}^{-1}\left(1.6 \mathrm{~kg} \cdot \mathrm{m}^{-3}\right) \mathrm{and} 99.8$ $\mathrm{mm} \cdot \mathrm{t}^{-1}\left(1.1 \mathrm{~kg} \cdot \mathrm{m}^{-3}\right)$, respectively. These results indicate that water use efficiency decreases with the increase of the quantity of water applied by irrigation.

A similar trend was also observed by some authors in the culture of sugarcane. The example of Singh [13], in subtropical India, finds that the sugarcane irrigated with only $25 \%$ of the evaporation of class "A" (EV) produced $78 \mathrm{~kg} \cdot \mathrm{ha}^{-1} \cdot \mathrm{mm}^{-1}\left(12.8 \mathrm{~mm} \cdot \mathrm{t}^{-1}\right)$ and to irrigate $125 \%$ of $\mathrm{EV}$, the water use efficiency (WUE) dropped to $59 \mathrm{~kg} \cdot \mathrm{ha}^{-1} \cdot \mathrm{mm}^{-1}$, equivalent to $16.9 \mathrm{~mm} \cdot \mathrm{t}^{-1}$.

In South Texas-USA, Wiedenfeld and Enciso [14] observed for the values of 1.00, 1.25 and 1.50 for the maximum kc of sugarcane (equivalent to $100 \%, 125 \%$ and $150 \%$ of ETo) the water use efficiency (WUE) in plant cane of 8.0, 7.5 and $6.0 \mathrm{Mg} \cdot \mathrm{mL}^{-1}$ (equivalent to $12.50,13.33$ and $16.67 \mathrm{~mm} \cdot \mathrm{t}^{-1}$ ), respectively; in soca cane the water use efficiency (WUE) was 9.4, 8.1 and 7.7 $\mathrm{Mg} \mathrm{mL}^{-1}$ (equivalent to 10.64, 12.34 and $12.99 \mathrm{~mm} \cdot \mathrm{t}^{-1}$ ).

Analyzing the average within the potassic fertilization, there is an increase of efficiency of use of water in spikes green corn until treatment $\mathrm{K}_{4}$ (corresponding to potassium fertilization of $80 \mathrm{~kg} \cdot \mathrm{ha}^{-1}$, twice the recommended by soil analysis) being produced from $1.2 \mathrm{~kg} \cdot \mathrm{m}^{-3}$ at $\mathrm{K}_{0}$ to $2.7 \mathrm{~kg}$ of spikes per cubic meter of water, at $\mathrm{K}_{4}$.

The following treatment with potassium fertilizer $\mathrm{K}_{5}, 100 \mathrm{~kg} \cdot \mathrm{ha}^{-1}$, plants requiring more water to produce the 
Table 4. Efficiency of water user for ears of green corn production.

\begin{tabular}{|c|c|c|c|c|c|c|c|c|c|c|c|c|c|c|}
\hline \multirow{3}{*}{$\begin{array}{l}\text { Water slides } \\
\quad(\mathrm{mm})\end{array}$} & \multicolumn{12}{|c|}{ Potassium (K). $\mathrm{kg} \cdot \mathrm{ha}^{-1}$} & \multirow{2}{*}{\multicolumn{2}{|c|}{ Average }} \\
\hline & \multicolumn{2}{|c|}{$\mathrm{K}_{0}-0$} & \multicolumn{2}{|c|}{$\mathrm{K}_{1}-20$} & \multicolumn{2}{|c|}{$\mathrm{K}_{2}-40$} & \multicolumn{2}{|c|}{$\mathrm{K}_{3}-60$} & \multicolumn{2}{|c|}{$\mathrm{K}_{4}-80$} & \multicolumn{2}{|c|}{$\mathrm{K}_{5}-100$} & & \\
\hline & $\mathrm{mm} \cdot \mathrm{t}^{-1}$ & $\mathrm{~kg} / \mathrm{m}^{3}$ & $\mathrm{~mm} \cdot \mathrm{t}^{-1}$ & $\mathrm{~kg} / \mathrm{m}^{3}$ & $\mathrm{~mm} \cdot \mathrm{t}^{-1}$ & $\mathrm{~kg} / \mathrm{m}^{3}$ & $\mathrm{~mm} \cdot \mathrm{t}^{-1}$ & $\mathrm{~kg} / \mathrm{m}^{3}$ & $\mathrm{~mm} \cdot \mathrm{t}^{-1}$ & $\mathrm{~kg} / \mathrm{m}^{3}$ & $\mathrm{~mm} \cdot \mathrm{t}^{-1}$ & $\mathrm{~kg} / \mathrm{m}^{3}$ & $\mathrm{~mm} \cdot \mathrm{t}^{-1}$ & $\mathrm{~kg} / \mathrm{m}^{3}$ \\
\hline $\mathrm{W}_{1}-132$ & 64.2 & 1.6 & 44.1 & 2.3 & 31.1 & 3.3 & 19.5 & 5.4 & 21.0 & 4.9 & 26.5 & 4.0 & 34.4 & 3.6 \\
\hline $\mathrm{W}_{2}-264$ & 77.0 & 1.3 & 61.6 & 1.7 & 43.8 & 2.3 & 38.2 & 2.6 & 31.6 & 3.2 & 47.0 & 2.1 & 49.9 & 2.2 \\
\hline $\mathrm{W}_{3}-396$ & 83.7 & 1.2 & 71.7 & 1.5 & 48.1 & 2.1 & 42.3 & 2.4 & 41.9 & 2.4 & 50.0 & 2.0 & 56.3 & 1.9 \\
\hline$W_{4}-528$ & 90.1 & 1.1 & 57.5 & 1.8 & 54.0 & 1.9 & 50.7 & 2.0 & 51.6 & 1.9 & 65.4 & 1.5 & 61.6 & 1.7 \\
\hline $\mathrm{W}_{5}-660$ & 81.4 & 1.2 & 99.3 & 1.0 & 65.2 & 1.5 & 53.8 & 1.9 & 49.6 & 2.1 & 62.4 & 1.6 & 68.6 & 1.6 \\
\hline $\mathrm{W}_{6}-792$ & 140.3 & 0.7 & 128.2 & 0.8 & 90.3 & 1.1 & 81.1 & 1.3 & 67.9 & 1.5 & 90.9 & 1.1 & 99.8 & 1.1 \\
\hline Average & 89.4 & 1.2 & 77.1 & 1.5 & 55.4 & 2.0 & 47.6 & 2.6 & 43.9 & 2.7 & 57.0 & 2.1 & & \\
\hline
\end{tabular}

same amount of spikes, $57 \mathrm{~mm} \cdot \mathrm{t}^{-1}\left(2.1 \mathrm{~kg} \cdot \mathrm{m}^{-3}\right)$. This peculiarity can be explained by disproportionality factor caused by excess potassium in the rhizosphere of plants subjected to treatment $\mathrm{K}_{5}$. For the "Law of the Minimum” Liebig, all nutrients must be available to the plant, the quantity and the ideal proportion. Bozkurt [15] conducting studies on the effects of irrigation with different water levels in the corn crop in Hatay, Turkey $\left(36^{\circ} 04^{\prime} \mathrm{N}, 35^{\circ} 57^{\prime} \mathrm{E}, 3 \mathrm{~m}\right.$ above the sea), observed in water use efficiency (WUE) for the production of grain from 0.53 to $1.77 \mathrm{~kg} \cdot \mathrm{m}^{-3}$, applied to the plants 182 - $508 \mathrm{~mm}$ water, respectively. Karimi and Gomrokchi [16] evaluated the water use efficiency (WUE) in irrigation systems furrow in Ghazvin Province, Iran ( $36^{\circ} 15^{\prime} \mathrm{N}, 49^{\circ} 54^{\prime} \mathrm{E}$ ), have obtained water use efficiency (WUE) in the production of maize, between 0.92 and $1.96 \mathrm{~kg} \cdot \mathrm{m}^{-3}$.

\section{Conclusion}

Based on the results of this research, it is concluded that the consumption of water to produce one ton of ears of corn, within all treatments of K fertilization, increased as a function of the layers of water (132, 264, 396, 528, 660 , and $792 \mathrm{~mm}$ of water), thus decreasing the water use efficiency (WUE).

The application of $680.64 \mathrm{~mm}$ of water and $72.14 \mathrm{~kg} \cdot \mathrm{ha}^{-1}$ potassium maximized the yield of ears, resulting in the maximum yield of ears of $10.82 \mathrm{t} \cdot \mathrm{ha}^{-1}$.

\section{Acknowledgements}

To Coordination of Improvement of Higher Education Personnel (CAPES) for the award of the scholarship for the first author during the graduate school.

\section{References}

[1] Costa, C.T.F., Pereira, L.G.R., Antos, R.D., Neves, A.L.N., Araújo, G.G.L., Barreiros, D.C. and Aragão, A.S.L. (2008) Produtividade e características agronômicas de sete genótipos de milho na região do sub-médio do vale do São Francisco. Proceedings of the 5th Congresso Nordestino de Produção Animal, Aracaju-SE, 2008.

[2] Link, J., Graeff, S., Batchelor, W. and Claupein, W. (2006) Evaluating the Economic and Environmental Impact of Environmental Compensation Payment Policy under Uniform and Variable-Rate Nitrogen Management. Agricultural Systems, 91, 135-153. http://dx.doi.org/10.1016/j.agsy.2006.02.003

[3] Puppala, N., Fowler, J.L., Jones, T.L., Gutschick, V. and Murray, L. (2005) Evapotranspiration, Yield, and Water-Use Efficiency Responses of Lesquerella Fendleri at Different Growth Stages. Industrial Crops and Products, 21, 33-47. http://dx.doi.org/10.1016/j.indcrop.2003.12.005

[4] El-Hendawy, S.E., Abd El-Lattief, E.A., Ahmed, M.S. and Schmidhalter, U. (2008) Irrigation Rate and Plant Density Effects on Yield and Water Use Efficiency of Drip-Irrigated Corn. Agricultural Water Management, 95, 836-844. http://dx.doi.org/10.1016/j.agwat.2008.02.008

[5] El-Hendawy, S.E. and Schmidhalter, U. (2010) Optimal Coupling Combinations between Irrigation Frequency and Rate for Drip-Irrigated Maize Grown on Sandy Soil. Agricultural Water Management, 97, 439-448. http://dx.doi.org/10.1016/j.agwat.2009.11.002

[6] Agência Executiva de Gestão das Águas do Estado da Paraíba (AESA) (2014) http://www.aesa.pb.gov.br

[7] Empresa Brasileira De Pesquisa Agropecuária (Embrapa) (1997) Manual de métodos de análise de solo. Centro Na- 
cional de Pesquisa de Solos, Rio de Janeiro.

[8] Cavalcanti, F.J.A. (Coord) (2008) Recomendação de adubação para o Estado de Pernambuco: Segunda aproximação. Instituto Agronômico de Pernambuco, IPA, Recife.

[9] Bernardo, S., Soares, A.A. and Mantovani, E.C. (2006) Manual de irrigação. Viçosa, MG.

[10] Paiva Júnior, M.C., Pinho, R.G., Pinho, E.V.R. and Resende, S.G. (2001) Desempenho de cultivares para a produção de milho verde em diferentes épocas e densidades de semeadura em Lavras-MG. Ciência e Agrotecnologia, 25, 12351247.

[11] Albuquerque, C.J.B., Von Pinho, R.G. and Silva, R. (2008) Produtividade de híbridos de milho verde experimentais e comerciais. Bioscience Journal, 24, 69-76.

[12] Moraes, A.R.A., Ramos Júnior, E.U., Gallo, P.B., Paterniani, M.E.A.G.Z., Swasaki, E., Duarte, A.P., Bernini, C.S. and Guimarães, P. (2010) Desempenho de oito cultivares de milho verde na safrinha, no estado de São Paulo. Revista Brasileira de Milho e Sorgo, 9, 79-91.

[13] Singh, P.N., Shukla, S.K. and Bhatnagar, V.K. (2007) Optimizing Soil Moisture Regime to Increase Water Use Efficiency of Sugarcane (Saccharum spp. Hybrid Complex) in Subtropical India. Agricultural Water Management, 90, 95100. http://dx.doi.org/10.1016/j.agwat.2007.02.008

[14] Wiedenfeld, B. and Enciso, J. (2008) Sugarcane Responses to Irrigation and Nitrogen in Semiarid South Texas. Agronomy Journal, 100, 655-671. http://dx.doi.org/10.2134/agronj2007.0286

[15] Bozkurt, S., Yazar, A. and Mansuroglu, G.S. (2011) Efects of Different Drip Irrigation Levels on Yield and Some Agronomic Characteristics of Raised Bed Planted Corn. African Journal of Agricultural Research, 6, 5291-5300.

[16] Karimi, M. and Afshin Gomrokchi, A. (2011) Yield and Water Use Efficiency of Corn Planted in One or Two Rows and Applying Furrow or Drip Tape Irrigation Systems in Ghazvin Province, Iran. Irrigation and Drainage, 60, 35-41. http://dx.doi.org/10.1002/ird.562 